\title{
Regeneration-degeneration processes in the inland dune forests in protected areas of central Poland (Kampinos National Park)
}

\begin{abstract}
The aim of our study was to quantify the differences in the regenerationdegeneration processes in pine and mixed oak-pine forest habitats in the Kampinos Forest (central Poland). We investigated whether the regeneration rate depends on habitat type, whether there is a relationship between the bilberry (Vaccinium myrtillus) cover and the degree of community deformation, and which habitat type has been most invaded by alien plant species. Our results indicate that the constant loss of pine forest habitats, which has been observed since the 1970s, is continuing. The less deformed communities generally have more bilberry coverage, the stands in pine forest habitats are older and less deformed, and the stands in mixed oak-pine forest habitats are more susceptible to the spread of alien species, but are able to regenerate faster after a disturbance. These results are in line with observations from other parts of Poland and other European countries.
\end{abstract}

Keywords

Pine forests - mixed oak-pine forests - regeneration • inland dunes • Kampinos National Park • central Poland

C University of Warsaw - Faculty of Geography and Regional Studies

\author{
Anna Kowalska, Ewa Kołaczkowska \\ Institute of Geography and Spatial Organisation \\ PAS, Poland \\ e-mail: aniak@twarda.pan.p \\ e-mail: ekolaczk@twarda.pan.pl \\ Received: 8 January 2015 \\ Accepted: 25 November 2015
}

Introduction

Vegetation dynamics comprises (following Faliński 1986) two distinctly directional processes - succession and regression - as opposite, reversible processes consisting of irregular changes which occur at variable intervals, i.e. the fluctuation, degeneration and regeneration of phytocenoses, and strictly cyclic and periodical processes such as seasonality. As degeneration, regeneration and fluctuation do not lead to irreversible changes in the structure and function of phytocoenoses and as they ensure their stability (permanence) they may be called the internal dynamics of the phytocoenosis (Pawłowski \& Zarzycki 1972). The terms degeneration and regeneration refer to the disintegration and reconstruction, respectively, of structures specific to a given phytocoenosis under the influence of external factors (Faliński 1986).

The regeneration of forest communities depends on a number of different factors, including past land-use, habitat type, forest persistence (temporal habitat continuity) and stand age, as well as management practices. Forest persistence over time is the most important factor in community regeneration (Matuszkiewicz et al. 2013a). The floristic composition of recent, usually postagricultural forests is very different from that of ancient forests (Peterken 1977; Rackham 1980; Dzwonko \& Gawroński 1994; Wulf 2003; Matuszkiewicz et al. 2013b), because forest species' recovery is very slow. Forest floor plants have specific biological traits (including shade tolerance, low dispersal capacity, limited mobility outside the forest environment, and the requirement of specific soil conditions) and lack the ability to compete with common species with wider ecological amplitude (Brunet \& von Oheimb 1998; Dzwonko \& Loster 2001; Hermy \& Verheyen 2007). Agricultural land use has persistent effects on soil properties, even after several decades or centuries. Land cultivation brings about changes of the water balance, soil reaction and biochemical components (Verheyen et al. 1999; Dupouey et al. 2002; Flinn \& Marks 2007).

The regeneration process in old-growth forests depends mainly on the management practices undertaken in the ecosystem, such as the introduction of plant species and the creation of clearings by felling trees, as well as animal grazing pressure (wild and livestock), the gathering of firewood and other activities (Kirby 2001; Zielony 2004a; Olofsson et al. 2005). These factors limit or promote the development of specific species and influence plant community structure and habitat conditions. The introduction of invasive alien plant species to a forest usually leads to aggregations of one dominant species and community degeneration (Tokarska-Guzik 2005). On the other hand, there are species which speed up the regeneration process, for instance bilberry Vaccinium myrtillus $\mathrm{L}$. This is one of the most important components of the herb layer in the pine and mixed oak-pine forests of the northern hemisphere. It contributes significantly to biomass production and to the matter cycle of substances rich in elements that are important to forest ecosystems (Moszyńska 1983). The presence of bilberry prevents soil erosion (Gadziński 1967 ) and promotes the formation and accumulation of a humus layer (Grochowski 1976) and the renewal of tree species (Jäderlund et al. 1996), as well as the development of other underground species (Parlane et al. 2006).

Kampinos National Park is a good example of postglacial valley relief with different types of inland dunes. The forest habitats have a long history of change and are worthy of study. In the 1960s, pine forest habitats dominated the dune fields, but 


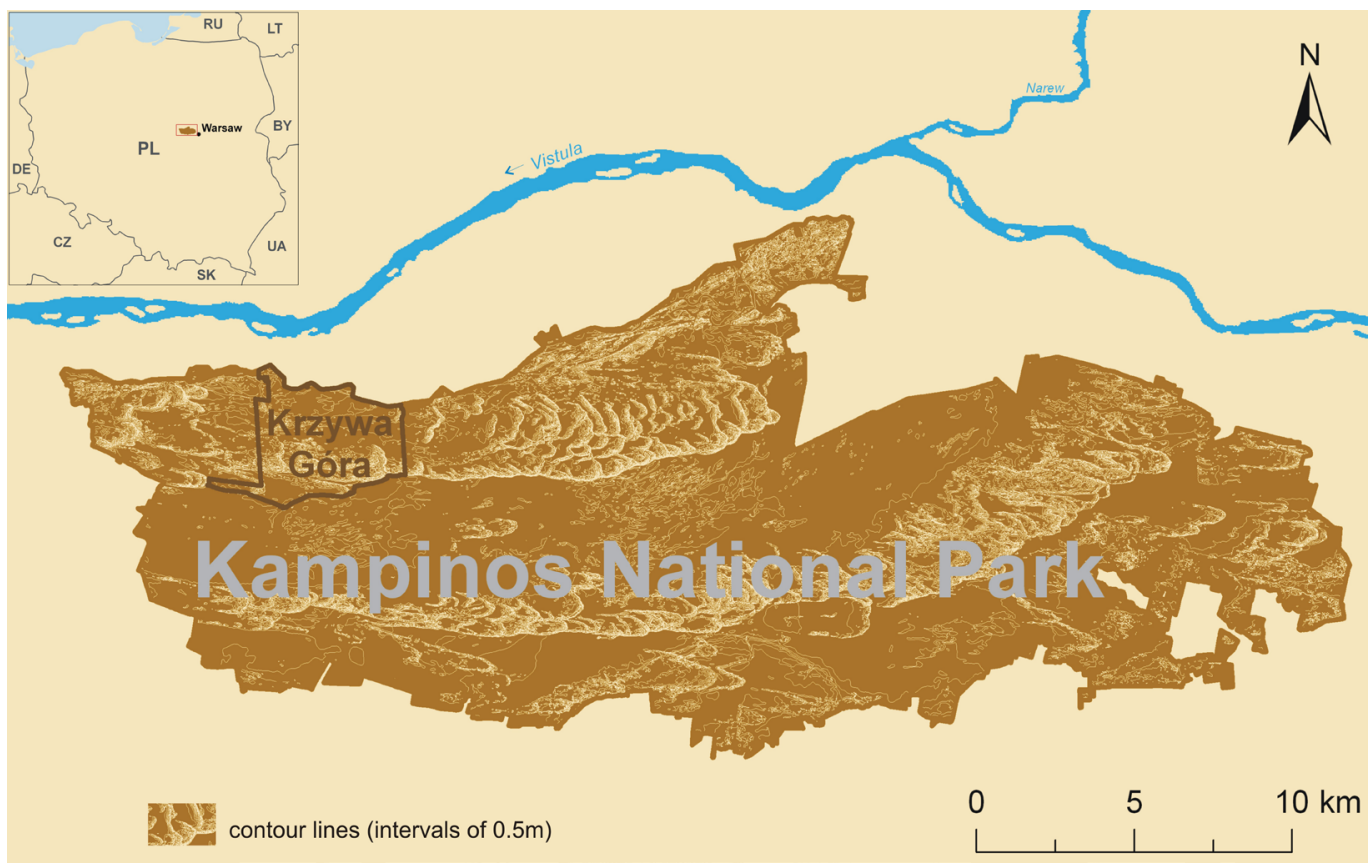

Figure 1. Location of the Kampinos National Park and the study area (Krzywa Góra forest division) within the Park

thirty years later their area had been diminished by almost half. They were mostly replaced by mixed oak-pine forest habitats, a change that was difficult to explain (Solon 2003). With these changes in mind, the aim of the present study was to quantify the differences in the regeneration-degeneration processes in pine and mixed oak-pine forest habitats. We looked at whether the actual plant communities were consistent with potential natural vegetation types (the concept of potential natural vegetation introduces the idea of the expected state of mature vegetation in the absence of human intervention - Tüxen 1956), with regard to plant species composition and tree stand structure. We investigated: (i) whether the regeneration rate of a specific forest community depends on habitat type, as has been observed in other studies (Matuszkiewicz et al. 2013a); (ii) whether there is a relationship between bilberry cover and the degree of community deformation, and (iii) which habitat type is more exposed to degeneration caused by alien plant species.

Materials and methods

Study area

The study was conducted in the northern dune belt of the Kampinos National Park, in the Krzywa Góra division (1522 ha) (Fig. 1). The whole Park covers 38,500 ha and was established in 1959 to maintain the unique complex of inland dunes and wetlands with their landscape and biological diversity.

Parabolic and ridged dunes of different sizes dominate in the Krzywa Góra division. The dunes have been stabilized mainly by pine and mixed oak-pine forests (Fig. 2). Most of the stands are considered to be ancient forests, as they have persisted in the landscape for at least 200 years. Their existence is documented in the Topographic Map of the Polish Kingdom of 1839, and in subsequent maps of the area (Kowalska 2006). Only the current forest patches located along the southern and northern borders of the study area are growing on former agricultural lands, which have been assigned to the Park over the last few decades. Thus the Krzywa Góra division may be considered a model subject for studying dynamic processes in pine and mixed oak-pine forests. The pine forests are represented by two phytosociological associations: Peucedano-Pinetum W.MAT. (1962) 1973 and Leucobrio-Pinetum W.MAT. (1962) 19731. They have been considered together due to the frequent coexistence of their characteristic species on the edge of their range. The mixed oak-pine forests are mainly represented by the Querco roborisPinetum (W.MAT. 1981) J.MAT. $1988^{2}$ association.

\section{Data collection and analysis}

The habitat type, the actual plant community phytosociological type and the degree of vegetation deformation were all diagnosed for each distinguished forest patch on the basis of vegetation field mapping conducted in summer and early autumn 2013. The community deformation was defined as the dissimilarity of a given forest patch in terms of species composition and vertical structure to the potential natural vegetation (sensu Tüxen 1956), phytosociologically, at the level of potential natural association (PNA). It was assessed using a seven-degree (0-6) ordinal scale, where 0 means no deformation and 6 means severe deformation, i.e. a community being beyond the scope of the potential natural association (Matuszkiewicz \& Solon 2006) (Table 1).

'The characteristic species combination of the Peucedano-Pinetum association consists of $\mathrm{ChCl}$ : Dicranum scoparium Hedw., Pleurozium schreberi (WILLD. EX BRID.) MitT., Hylocomium splendens (Hedw.) Schimp., Melampyrum pratense L., Ptilium cristacastrensis (Hedw.) De Not., Trientalis europaea L., Vaccinium myrtillus L., Vaccinium uliginosum $\mathrm{L}$., Vaccinium vitis-idaea $\mathrm{L}$.; $\mathrm{ChO}$ : Pinus sylvestris $\mathrm{L}$., Cladonia rangiferina (L.) NYL., Cladonia arbuscula (WALLR.) FLotow, Dicranum polysetum EHRH. EX F. Weber et D. Mohr.; ChAll.: Chimaphila umbellata (L.) W. P. C. BARTon, Diphasiastrum complanatum (L.) HoLuB, Monotropa hypopitys L. S. STR., Pyrola chlorantha Sw.; DAss. Peucedanum oreoselinum (L.) MoENCH, Convallaria majalis L., Polygonatum odoratum (MILL.) DRUCE, Pulsatilla patens (L.) MILL., Scorzonera humilis L., Solidago virgaurea L. In comparison, Leucobrio-Pinetum is poorer in plant species but is characterized by a great abundance of Leucobrium glaucum (HEDW.) ÂNGsTR., Deschampsia flexuosa (L.) Trin., Hypnum cupressiforme Hedw. and Fagus sylvatica L. (DAss.). The latter is an alien species in this part of Poland (Matuszkiewicz 2001).

${ }^{2}$ Elements of the Vaccinio-Piceetalia order dominate in its characteristic species combination, but species of the Querco-Fagetea class (Carex digitata L., Carpinus betulus L., Corylus avellana L., Euonymus verrucosa Scop., Melampyrum nemorosum L., Melica nutans L., Mycelis muralis (L.) Dumort., Quercus petraea (MATT.) LIEBL., Quercus robur L., Viola reichenbachiana BOREAU) are constantly observed. Pine and oak co-dominate in the stand but oak Quercus robur has greater significance (Matuszkiewicz 2001). 
MISCELLANEA GEOGRAPHICA - REGIONAL STUDIES ON DEVELOPMENT

Vol. $19 \cdot$ No. 4 • 2015 • pp. 56-63 • ISSN: 2084-6118 • DOI: 10.1515/mgrsd-2015-0028

Table 1. The seven-degree scale of vegetation deformation used in the field study (according to Matuszkiewicz \& Solon 2006)

\begin{tabular}{|c|c|}
\hline $\begin{array}{c}\text { Degree of } \\
\text { deformation }\end{array}$ & Characteristics \\
\hline 0 & $\begin{array}{c}\text { No deformation - actual community resembles } \\
\text { perfectly a particular potential natural } \\
\text { association (Matuszkiewicz JM 2001) in } \\
\text { terms of floristic composition and stand and } \\
\text { undergrowth structure (presence of very old } \\
\text { trees and dead wood), without alien species } \\
\text { and soil ground cover transformation. }\end{array}$ \\
\hline 1 & $\begin{array}{c}\text { Minimal deformation - as above, but } \\
\text { characteristic species composition represented } \\
\text { in at least 80\%. }\end{array}$ \\
\hline 2 & $\begin{array}{c}\text { Slight deformation - floristic composition } \\
\text { is consistent with characteristic species } \\
\text { composition, with small gaps and few } \\
\text { species alien to the association (50-80\% of } \\
\text { characteristic species). Stand structure may } \\
\text { be changed in terms of age and composition } \\
\text { (equal-age of trees; gaps in the stand; absence } \\
\text { of typical, secondary species; greater cover } \\
\text { of additional species) or overdeveloped } \\
\text { undergrowth. }\end{array}$ \\
\hline 3 & $\begin{array}{c}\text { Significant deformation - floristic composition } \\
\text { and stand and undergrowth structure distinctly } \\
\text { depart from the PNA (only one typical } \\
\text { species in the stand; typical species only in } \\
\text { the undergrowth, domination of ecologically/ } \\
\text { geographically alien or additional species; 35- } \\
\text { 50\% of characteristic species composition). }\end{array}$ \\
$\begin{array}{c}\text { Big deformation - there are big gaps in } \\
\text { characteristic species composition (presence } \\
\text { of 20-35\% of species) and stand structure } \\
\text { significantly changed. }\end{array}$ \\
$\begin{array}{c}\text { Very big deformation - community is hardly } \\
\text { identified (under 20\% of characteristic species). }\end{array}$ \\
\hline 5
\end{tabular}

The forest patches established in pine and mixed oak-pine forest habitats were also compared with each other in terms of the stand age identified from the existing forest map. Additionally, each forest patch was characterised by the percentage of bilberry cover (a projection of leaved heads of shrubs expressed in percentage terms) and the presence or absence of alien plant species (giant goldenrod Solidago gigantea AITON, black cherry Prunus serotina EHRH., black locust Robinia pseudoacacia L. and red oak Quercus rubra L.).

To explore the differences in the regeneration process across pine and mixed oak-pine habitats, the percentage share of forest patches classified to a certain deformation degree was calculated. Spearman's rank correlation test was used to examine the relationships between the stand age and the degree of deformation in each habitat type as well as to correlate the cover of bilberry with the degree of community deformation and the stand age. For these analyses, we selected mature stands, i.e. those aged over 50 years (according to the forest stand classification for Polish forests by Andrzejewski 1991).

Fisher's exact probability test was used to compare the frequency of occurrence of alien species in the habitat types, combined with the stand age categories.

The statistical analyses were carried out using the Statistica 7.1 software package.

Results

Pine and mixed oak-pine forest habitats cover $92 \%$ of the study area. The areal ratio of these habitats is 1:6 (198:1199 ha), with dominant mixed oak-pine forests surrounding pine forests (Fig. 2). This corresponds closely to the ratio calculated for the whole area of dune belts in the park, 1:5 (2450:14039 ha).

We distinguished 53 patches of pine forest and 295 patches of mixed oak-pine forest habitats in the studied division. A considerable amount of forest phytocoenoses in the mixed oak-pine forest habitats was beyond the scope of the PNA (category 6) - 45\% (541 ha), compared to $36 \%$ (71 ha) in the pine forest habitats. Their stands were generally built by native species: Scots pine Pinus sylvestris, silver birch Betula pendula and/or English oak Quercus robur - but their structure was severely deformed (young or equal-aged trees, numerous gaps in the stand, co-domination of alien or additional species) and the species composition of the undergrowth was very limited

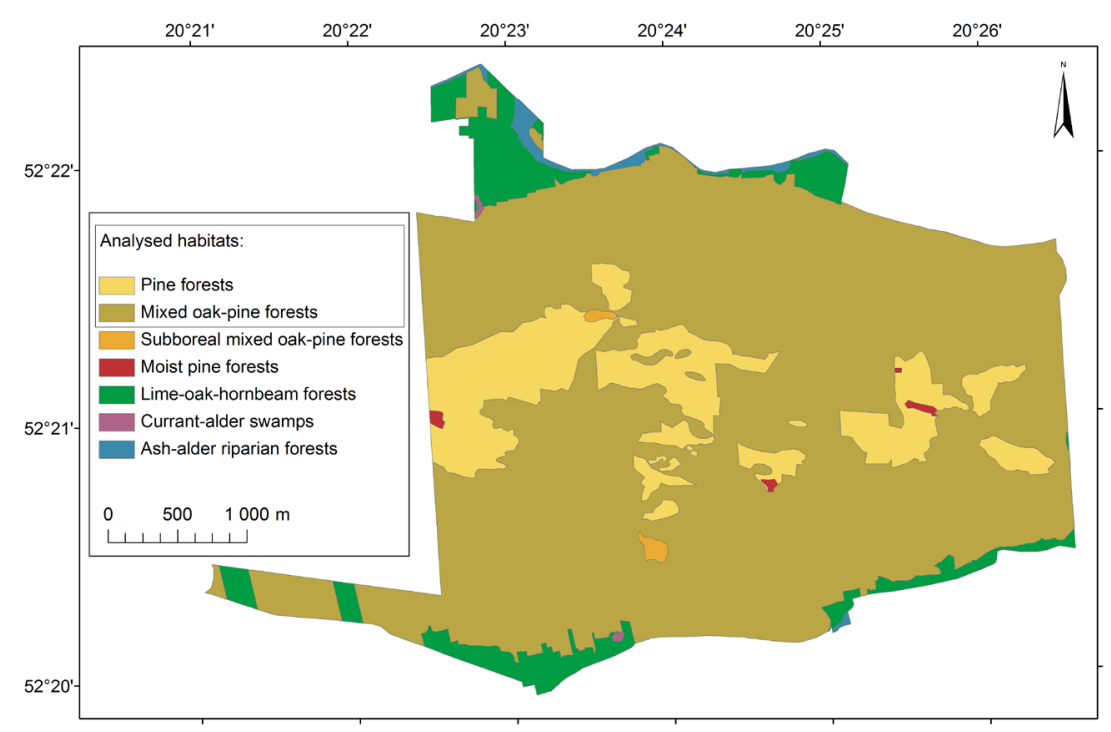

Figure 2. Distribution of potential natural vegetation (habitats) in the study area 


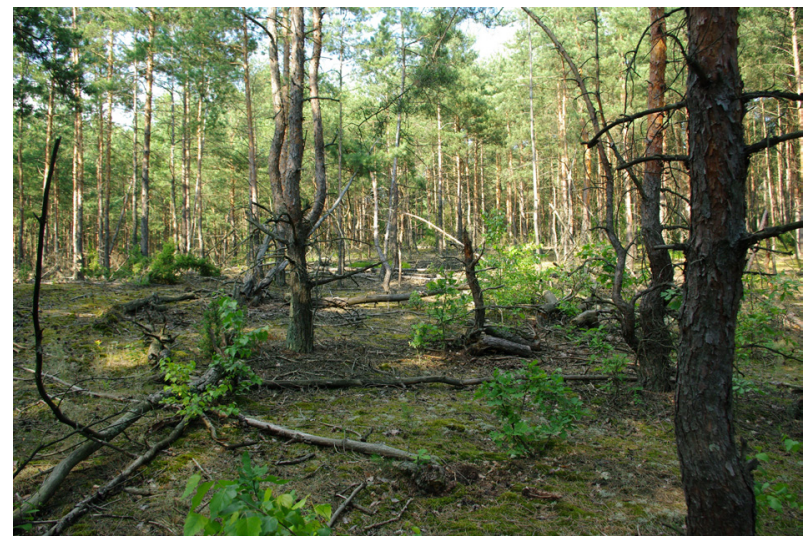

Photo 1. Entirely deformed pine forest ( $6^{\text {th }}$ degree of deformation) Author: Ewa Kołaczkowska

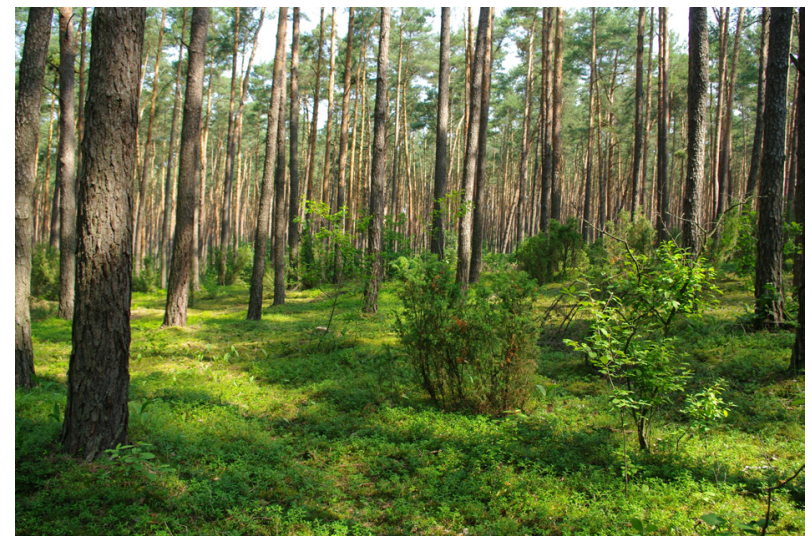

Photo 2. Well-developed pine forest (2 ${ }^{\text {nd }}$ degree of deformation) Author: Ewa Kołaczkowska

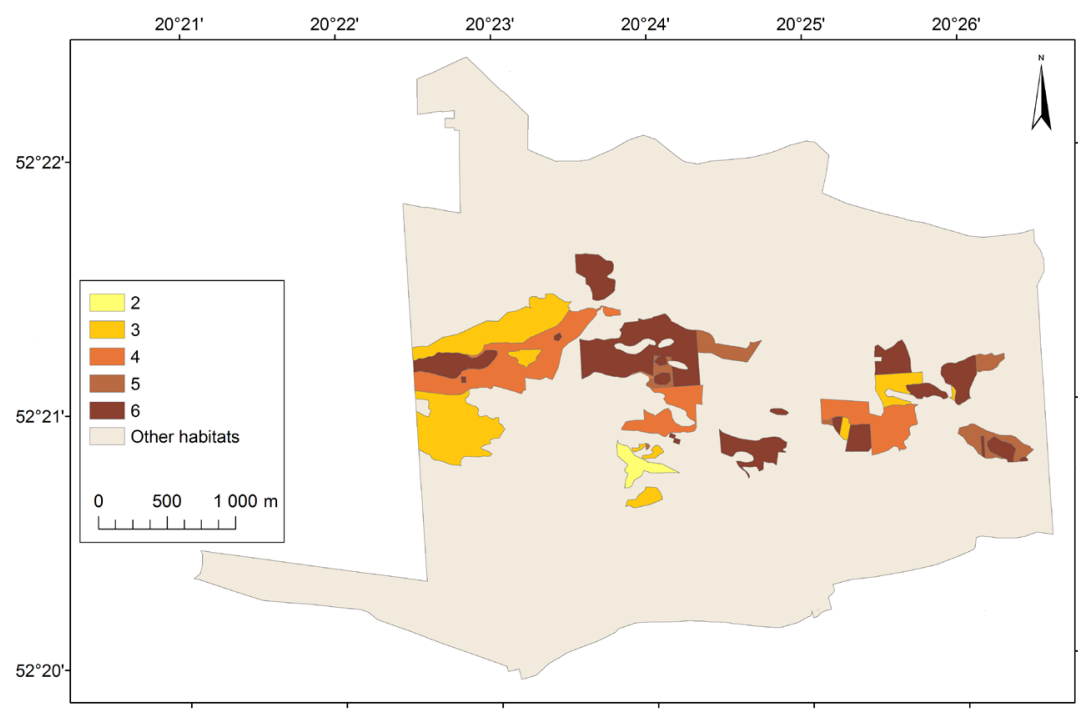

Figure 3. Deformation of the pine forest communities in the study area according to the seven-degree (0-6) scale of vegetation deformation (0 and 1 were not observed)

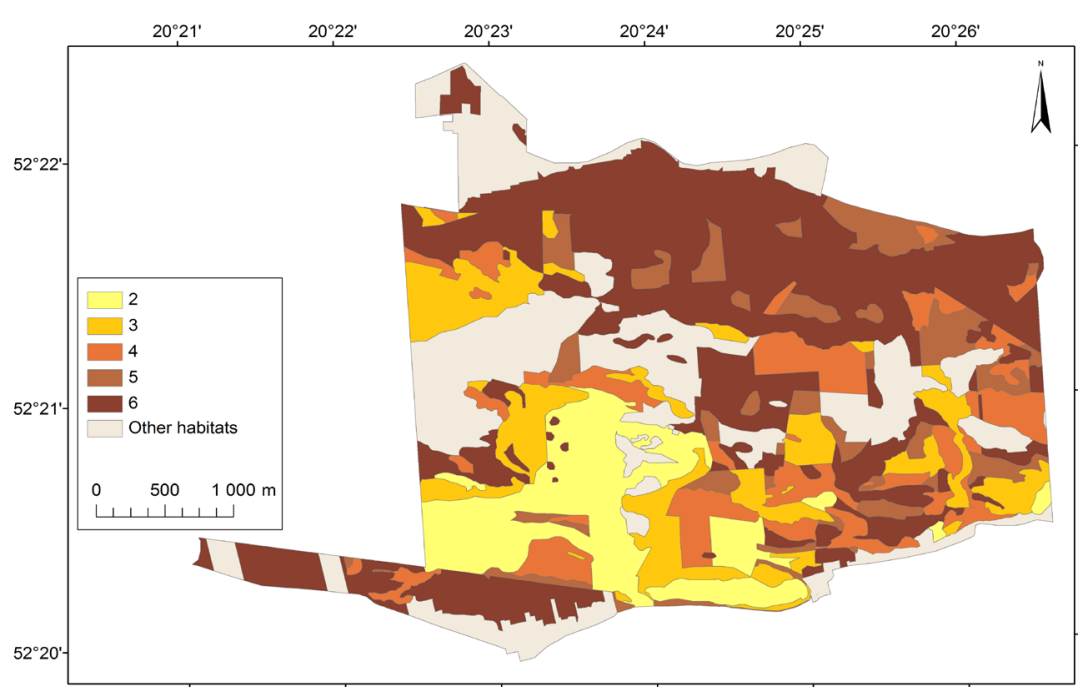

Figure 4. Deformation of the mixed oak-pine forest communities in the study area according to the seven-degree (0-6) scale of vegetation deformation ( 0 and 1 were not observed) 
(Photo 1). These forest phytocoenoses were not sufficiently developed for them to be assigned to a certain phytosociological association. However, some patches - usually those with mature stands - were identified phytosociologically as examples of the Dicrano-Pinion W. MAT. 1962 alliance $^{3}$.

Stands younger than 50 years accounted for $10 \%$ (124 ha) of mixed oak-pine forest habitats and $2.5 \%$ (5 ha) of pine forest habitats.

The most natural patches were located in the southern and middle parts of the study area, although no examples of undeformed communities (category 0 ), nor anything very similar (category 1), were observed in both habitat types. Well-developed phytocoenoses (2-4) accounted for $57 \%$ (127 ha) of pine forest habitats and $44 \%$ (658 ha) of mixed oak-pine forest habitats (Fig. 3, 4, 5, Photo 2).

There was no correlation between the degree of deformation and forest stand age (excluding the young stands) (Table 2). Although they were weakly negatively correlated in the case of the pine forest habitats (the patches with older stands resembled their
PNA more than those with younger stands), this relationship was not significant (Table 2). We found many examples of stands which were over 90 years old and were far from their potential natural state. The specific features of such stands in mixed oak-pine forest habitats suggest that they were former pine forests (Table 2).

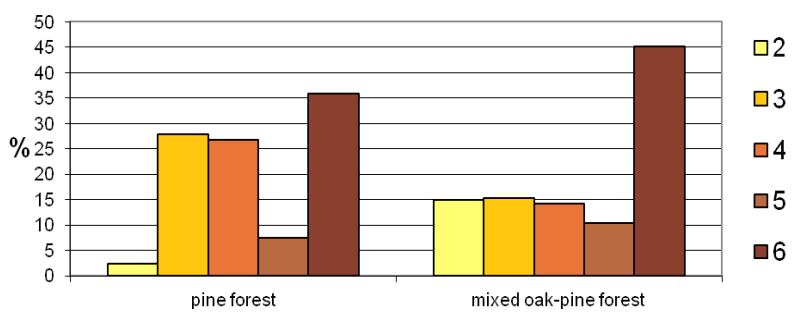

Figure 5. The percentage of pine and mixed oak-pine forests in the study area that have been deformed according to the sevendegree (0-6) scale of vegetation deformation ( 0 and 1 were not observed)

Table 2. Correlations between chosen ecological parameters of the phytocoenoses developed in the pine forest habitats $P F$ and in the mixed oak-pine forest habitats MF; forest stands aged under 50 are not considered; $N_{P F}=53, N_{M F}=295$

\begin{tabular}{|c|c|c|c|}
\hline Variables & Habitat type & Spearman rs statistic & $p$ (uncorr.) \\
\hline \multirow{2}{*}{ Degree of deformation (0-6) vs. forest stand age (yrs) } & PF & -0.250 & 0.071 \\
\cline { 2 - 4 } & MF & -0.037 & 0.530 \\
\hline \multirow{2}{*}{ Degree of deformation (0-6) vs. cover of bilberry (\%) } & PF & -0.331 & 0.015 \\
\cline { 2 - 4 } & MF & -0.211 & $<0.001$ \\
\hline \multirow{2}{*}{ Forest stand age (yrs) vs. cover of bilberry (\%) } & PF & 0.402 & 0.003 \\
\cline { 2 - 4 } & MF & 0.246 & $<0.001$ \\
\hline
\end{tabular}

Table 3. Frequency of occurrence of alien species in the forest patches. Test of the frequency difference between the forest categories (habitat type and stand age) according to Fisher's exact test: bold indicates the significance of the test between categories $p \leq 0.05$; PF - pine forest habitats, MF - mixed oak-pine forest habitats; young - stands aged 50 or less; old - stands aged over 50; * high frequencies of occurrence of giant goldenrod and black cherry in young pine forests result from a small number of patches

\begin{tabular}{|c|c|c|c|c|c|c|c|c|c|c|}
\hline \multirow{2}{*}{$\begin{array}{l}\text { Name of alien } \\
\text { plant species }\end{array}$} & \multicolumn{4}{|c|}{$\begin{array}{c}\text { Frequency of occurrence of } \\
\text { alien species according to the } \\
\text { habitat types and the stand age } \\
\text { categories [\%] }\end{array}$} & \multicolumn{6}{|c|}{$p$ value } \\
\hline & $\begin{array}{c}\text { young } \\
\text { PF }\end{array}$ & $\begin{array}{l}\text { old } \\
\text { PF }\end{array}$ & $\begin{array}{c}\text { young } \\
\text { MF }\end{array}$ & $\begin{array}{l}\text { old } \\
\text { MF }\end{array}$ & $\begin{array}{c}\text { young PF } \\
\text { vs } \\
\text { old PF }\end{array}$ & $\begin{array}{c}\text { young PF } \\
\text { vs } \\
\text { young MF }\end{array}$ & $\begin{array}{l}\text { old PF } \\
\text { vs } \\
\text { old MF }\end{array}$ & $\begin{array}{l}\text { young MF } \\
\text { vs } \\
\text { old MF }\end{array}$ & $\begin{array}{c}\text { young PF } \\
\text { vs } \\
\text { old MF }\end{array}$ & $\begin{array}{l}\text { old PF } \\
\text { vs } \\
\text { young MF }\end{array}$ \\
\hline $\begin{array}{l}\text { giant goldenrod } \\
\text { Solidago } \\
\text { gigantea }\end{array}$ & $25.0^{*}$ & 0.0 & 8.5 & 1.2 & 0.07 & 0.31 & 1.00 & 0.00 & 0.07 & 1.00 \\
\hline $\begin{array}{c}\text { black cherry } \\
\text { Prunus serotina }\end{array}$ & $25.0^{*}$ & 0.0 & 18.2 & 6.5 & 0.07 & 0.56 & 0.06 & 0.00 & 0.29 & 1.00 \\
\hline $\begin{array}{l}\text { black locust } \\
\text { Robinia } \\
\text { pseudoacacia }\end{array}$ & 0.0 & 0.0 & 8.5 & 5.0 & 1.00 & 0.31 & 0.14 & 0.16 & 1.00 & 1.00 \\
\hline $\begin{array}{c}\text { red oak } \\
\text { Quercus rubra }\end{array}$ & 0.0 & 0.0 & 3.6 & 7.1 & 1.00 & 0.16 & 0.06 & 0.16 & 1.00 & 1.00 \\
\hline
\end{tabular}

${ }^{3}$ The alliances stand directly above the associations in the Braun-Blanquet phytosociological classification system. 


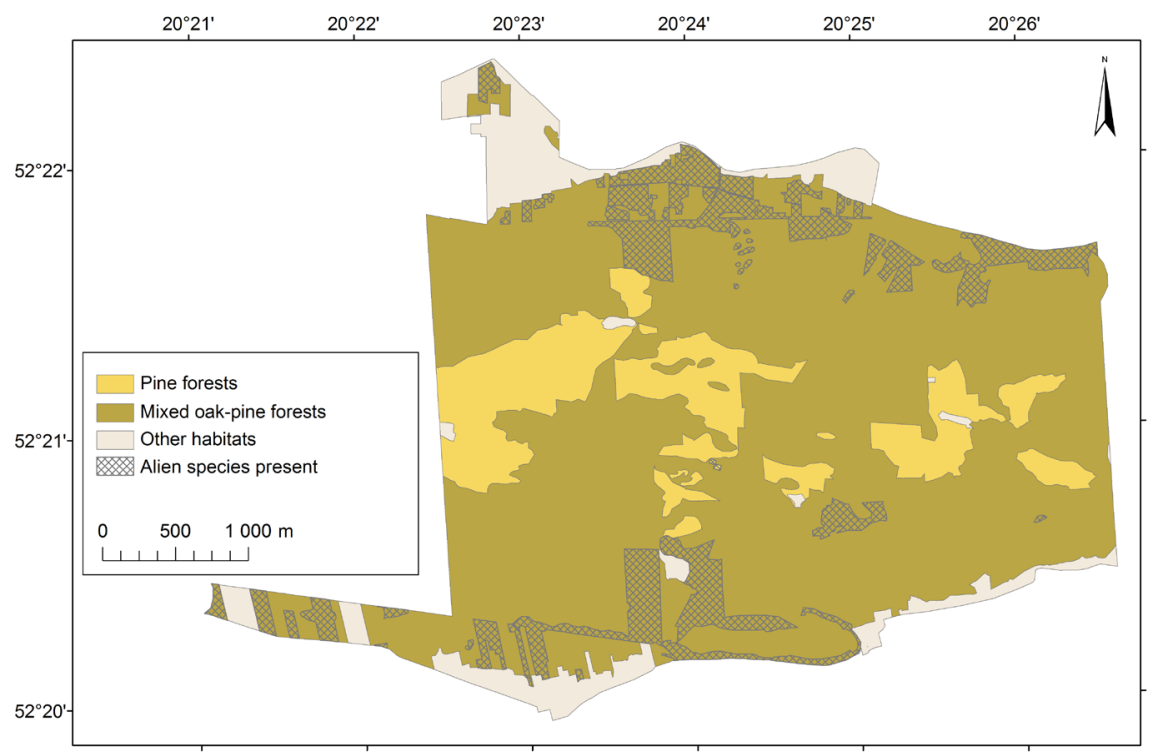

Figure 6. Distribution of alien species in the pine and mixed oak-pine forest habitats in the study area

We observed a general trend that the more natural the forest patch, the higher the bilberry Vaccinium myrtillus cover. This species is associated with ancient forests (Dzwonko \& Loster 2001), and this study confirms its greater abundance under older stands in both habitat types. Moreover, this correlation is stronger for the pine forests than for the mixed oak-pine forests (Table 2).

One of the most important factors hindering the regeneration of the PNA in the studied area was the occurrence of alien plant species. The most frequently noted aliens were four invasive ones: giant goldenrod Solidago gigantea AITON, black cherry Prunus serotina EHRH., black locust Robinia pseudoacacia L. and red oak Quercus rubra L. They were concentrated mainly at the edge of the forest, in the vicinity of human settlements, along paths and other routes (Fig. 6). Overall, they were most abundant in mixed oak-pine forest habitats and in forest communities under 50 years old. The only exception was red oak which was more frequent in the older stands. However, significant differences occurred only for giant goldenrod and black cherry, between young and old communities of mixed oak-pine forest habitats (Table 3).

\section{Discussion}

The physiognomy of the analysed forest area, as well as the main reasons behind the deformation of the plant communities identified during the field study, indicated that the most important factors responsible for the current distribution of the forest habitat types are land management practices. This also explains why some of the patches on the maps have angular shapes.

According to Kobendzina (1979), mixed oak-pine forests had historically dominated the inland dunes in Kampinos Forest, until human pressures changed the habitat. Heymanowski (1975) reported that oak trees were intensively felled for the ship-building industry and military purposes in the second half of the $19^{\text {th }}$ and beginning of the $20^{\text {th }}$ centuries. Further regression of the mixed oak-pine forest habitats was caused by forest destruction as a result of both World Wars. Deforested sites were left un-restocked, which also often led to secondary migration of the dunes. Forest exploitation and the large scale logging of broadleaved trees promoted the faster growth of the extant Scots pine, and limited the admixture of deciduous species.
The distribution of pine forest and mixed oak-pine forest habitats has varied extensively over the past 50 years. Maps of the potential natural vegetation of Kampinos National Park, which depict its state in the mid-1960s (Matuszkiewicz 1966), at the beginning of the 1980s (Matuszkiewicz 1982), and finally in the mid1990s (Solon 1994), show a decreasing area of pine forest habitats and an increasing area of mixed oak-pine forest habitats. Now, our research indicates that pine forest habitats are still in decline, most likely due to the regeneration of moister, more fertile habitats after the discontinuation of domestic livestock grazing in the forests, traditional litter raking in the Park in the late 1960s and early 1970s, as well as numerous oak plantings (Zielony 2004a). The transition from pine forests to mixed oak-pine forests has been described in the context of recovery processes from degradation in Poland (Dzwonko \& Gawroński 2002; ed Matuszkiewicz 2007; Stefańska-Krzaczek 2010) and in Central Europe (Heinken 2008; Reinecke et al. 2014).

The stands in the pine forest habitats have in general a better developed vertical structure than those in the mixed oak-pine forest habitats. However, the latter seem to regenerate faster due to the fact that even the phytocoenoses with immature stands (less than 50 years old) were developed in accordance with the potential natural vegetation. Our results are also in line with the observations of Matuszkiewicz et al. (2013a), who found that forest communities regenerate faster in more fertile habitats. They also proved that bilberry has a significant influence on undergrowth structure, and that this species was more abundant in ancient and older forests than recent forests (north-eastern Poland). The same was observed during the present study in Kampinos Forest and by Góras \& Orczewska (2007) in south-western Poland. Furthermore, our results are in line with other European studies (Sweden - Kardell 1980; Hedwall et al. 2013; Finland - Reinikainen et al. 2000; Germany - Jandt et al. 2011) showing that bilberry abundance increases with forest age but declines with tree density. This dwarf shrub decidedly prefers half-shade or moderate light under moderate canopy cover (Głowacki 1999; Ihalainen et al. 2002; Nielsen et al. 2007).

Alien species are not highly abundant in the Krzywa Góra division (often occurring singly in patches), and are generally more frequent in the more fertile, mixed oak-pine forest 
habitats and in young stands, which is in accordance with other observations. It was found that non-natives are more abundant in communities with a high degree of disturbance (Pyšek et al. 1995), and also in those with higher nutrient availability (Davis et al. 2000). The most explicit example of the negative influence of alien plant species on the forest vegetation is the spread of black cherry which constrains the development of other native species (Otręba 2014; Zielony 2004b). Introduced by foresters, this species is easily dispersed by frugivorous birds and some mammals (Otręba \& Mędrzycki 2009). The abundance of red oak is also associated with forest management. It was planted to improve habitat conditions, taking advantage of the fact that this species grows faster and is more tolerant of adverse climates, soil and light conditions than native oak species (Tomanek 1997). At present, red oak is rarely planted in Kampinos Forest, which is why it is more frequent in the older stands. The invasion of alien species is a common problem in other protected areas where they are chemically and mechanically controlled (Danielewicz \& Maliński 1997; Dajdok et al. 2007; ed Matuszkiewicz 2007).

\section{References}

Andrzejewski, R 1991, Mała encyklopedia leśna [Small forest encyclopedia], Wydawnictwo Naukowe PWN, Warszawa.

Brunet, J \& von Oheimb, G 1998, 'Migration of vascular plants to secondary woodlands in southern Sweden', Journal of Ecology vol. 86, pp. 429-438.

Dajdok, Z Krzysztofiak, A Krzysztofiak, L Romański, M \& Śliwiński M 2007, Rośliny inwazyjne w Wigierskim Parku Narodowym [Invasive plants in Wigierski National Park], Wigierski Park Narodowy, Krzywe.

Danielewicz, W \& Maliński, T 1997, 'Drzewa i krzewy obcego pochodzenia w lasach Wielkopolskiego Parku Narodowego' [Alien trees and shrubs in forests of Wielkopolski National Park], Rocznik dendrologiczny vol. 45, pp. 65-81.

Davis, MA Thompson, K \& Grime, JP 2000, 'Fluctuating resources in plant communities: a general theory of invasibility', Journal of Ecology vol. 88, pp. 528-534.

Dupouey, JL Dambrine, E Laffite, JD \& Moares, C 2002, 'Irreversible impact of past land use on forest soils and biodiversity', Ecology vol. 83, pp. 2978-2984.

Dzwonko, Z \& Gawroński, S 1994, 'The role of woodland fragments, soil types, and dominant species in secondary succession on the western Carpathian foothills', Vegetatio vol. 111, pp. 149-160.

Dzwonko, Z \& Gawronski, S 2002, 'Effect of litter removal on species richness and acidification of a mixed oak-pine woodland', Biological Conservation vol. 106, pp. 389-398.

Dzwonko, Z \& Loster, S 2001, 'Wskaźnikowe gatunki roślin starych lasów i ich znaczenie dla ochrony przyrody i kartografii roślinności' [Ancient woodland plant species indicators and their importance for nature conservation and vegetation mapping], Prace Geograficzne vol. 178, pp. 119-132.

Faliński, JB 1986, Vegetation Dynamics in Temperate Lowland Primeval Forests. Ecological Studies in Białowieża Forest, Springer, Netherlands.

Flinn, KM \& Marks, PL 2007, 'Agricultural legacies in forest environments: tree communities, soil properties and light availability', Ecological Applications vol. 17, pp. 452-463.

Gądziński, Z 1967, 'Warunki retencji wodnej w glebach leśnych' [Conditions of water retention in forest soils], Roczniki WSR, Poznań, Leśnictwo vol. 34(8), pp. 371-413.

Głowacki, S 1999, 'Badania nad jagodziskami borówki czernicy (Vaccinium myrtillus L.) występującymi na terenie Nadleśnictwa Mielec' [A research on areas overgrown by
In conclusion, the mixed oak-pine forest habitats are more susceptible to the spread of alien species, but they are able to regenerate faster after disturbance, provided that proper remedial actions are undertaken.

The processes observed in our study (habitat transition and the invasion of alien species) are in line with the trends emerging in other parts of Poland and Europe.

\section{Acknowledgments}

This research was supported by the National Fund for Environmental Protection and Water Management, within the framework of the Inventory and monitoring of biotic and abiotic nature in Kampinos National Park including Natura 2000 habitats and species project.

We would like to thank Prof. J. Matuszkiewicz for his valuable help during the field-work and corrections to the map of potential natural vegetation. bilberry (Vaccinium myrtillus L.) within the Mielec Forest District area], Sylwan vol. 6, pp. 29-38.

Góras, P \& Orczewska, A 2007, 'Zróżnicowanie runa w lasach sosnowych posadzonych na gruntach porolnych i w starych lasach sosnowych na siedlisku boru mieszanego świeżego' [Differentiation of the herbaceous layer of the post-arable and ancient pine forests developing on a habitat of recent mixed pine forests], Przegląd Przyrodniczy vol. 18(1-2), pp. 227-241.

Grochowski, W 1976, Uboczna produkcja leśna [Accessory forest production], Wydawnictwo Naukowe PWN, Warszawa.

Hedwall, P-O Brunet, J Nordin, A \& Bergh, J 2013, 'Changes in the abundance of keystone forest floor species in response to changes of forest structure', Journal of Vegetation Science vol. 24(2), pp. 296-306.

Heinken, T 2008, 'Vaccinio-Piceetea (H7) - BeerstrauchNadelwälder, Teil 1: Dicrano-Pinion - Sand- und SilikatKiefernwälder', in Synopsis der Pflanzengesellschaften Deutschlands ed Dierschke, H, Die Arbeitsgemeinschaft, Göttingen, DE, pp. 1-88.

Hermy, M \& Verheyen, K 2007, 'Legacies of the past in the present-day forest biodiversity: a review of past land-use effects on forest plant species composition and diversity', Ecological Research vol. 22, pp. 361-371.

Heymanowski, K 1975, 'Materiały do odtworzenia składu gatunkowego drzewostanów Kampinoskiego Parku Narodowego' [Materials for the reconstruction of species composition of forest stands in Kampinos National Park], Sylwan vol. 3, pp. 37-51.

Ihalainen, M Alho, J Kolehmainen, O \& Pukkala, T 2002, 'Expert models for bilberry and cowberry yields in Finnish forests', Forest Ecology and Management vol. 157, pp. 15-22.

Jäderlund, A Zackrisson, O \& Nilsson, MC 1996, 'Effects of bilberry (Vaccinium myrtillus L.) litter on seed germination and early seedling growth of four boreal tree species', Journal of Chemical Ecology vol. 22, pp. 973-986.

Jandt, U von Wehrden, H \& Bruelheide, H 2011, 'Exploring large vegetation databases to detect temporal trends in species occurrences', Journal of Vegetation Science vol. 22, pp. 957-972.

Kardell, L 1980, 'Occurrence and production of bilberry, lingonberry and raspberry in Sweden's forests', Forest Ecology and Management vol. 2, pp. 285-298. 
Kirby, KJ 2001, 'The impact of deer on the ground flora of British broadleaved woodland', Forestry vol. 74(3), pp. 219-229.

Kobendzina, J 1979, 'Zagadnienia przyszłości Puszczy Kampinoskiej' [lssues of Kampinos Forest future], in Kampinoski Park Narodowy i jego problematyka, Dokumentacja Geograficzna 1, Zakład Narodowy im. Ossolińskich, Wydawnictwo PAN, Wrocław, pp. 16-28.

Kowalska, A 2006, 'Land-use change in different natural habitats of the Vistula river valley during the 19th and 20th centuries', Geographia Polonica vol. 79(1), pp. 113-130.

Matuszkiewicz, JM 1982, 'Potencjalne zbiorowiska roślinne i potencjalne fitokompleksy krajobrazowe Północnego Mazowsza' [Potential plant communities and potential landscape phytocomplexes of northern Masovia], Monographiae Botanicae vol. 62, pp. 5-78.

Matuszkiewicz, JM 2001, Zespoły leśne Polski [Forest associations of Poland], Wydawnictwo Naukowe PWN, Warszawa.

Matuszkiewicz, JM (ed) 2007, Geobotaniczne rozpoznanie tendencji rozwojowych zbiorowisk leśnych $w$ wybranych regionach Polski [Geobotanical identification of the development tendencies in forest associations in the regions of Poland], Monografie 8, PAS, IG\&SO, Warszawa.

Matuszkiewicz, JM Kowalska, A Solon, J Degórski, M Kozłowska, A Roo-Zielińska, E Zawiska, I \& Wolski, J 2013a, 'Longterm evolution models of post-agricultural forests', Prace Geograficzne 240.

Matuszkiewicz, JM Kowalska, A Kozłowska, A Roo-Zielińska, E \& Solon, J 2013b, 'Differences in plant-species composition, richness and community structure in ancient and postagricultural pine forests in central Poland', Forest Ecology \& Management vol. 310, pp. 567-576.

Matuszkiewicz, JM \& Solon, J 2006, 'Forecasting of states of ecosystems in protected areas on the basis of a comprehensive digital vegetation map (as exemplified by Poland's Bory Tucholskie National Park)', Geographia Polonica vol. 79(1), pp. 65-94.

Matuszkiewicz, W 1966, 'Potencjalna roślinność naturalna Kotliny Warszawskiej' [Potential natural vegetation of Warsaw Cirque], Materiały Zakładu Fitosocjologii Stosowanej UW 15, pp. 1-14.

Matuszkiewicz, W 2001, Przewodnik do oznaczania zbiorowisk roślinnych Polski [A guide for the identification of Polish plant communities], Wydawnictwo Naukowe PWN, Warszawa.

Moszyńska, B 1983, 'Some problems of ecology of Vaccinium myrtillus L. in pine forest communities', Polish Ecological Studies vol. 9(4), pp. 565-643.

Nielsen, A Totland, $\varnothing$ \& Ohlson, M 2007, 'The effect of forest management operations on population performance of Vaccinium myrtillus on a landscape-scale', Basic Applied Ecology vol. 8, pp. 231-241.

Olofsson, J Hulme, PE Oksanen, L \& Suominen, O 2005, 'Effects of mammalian herbivores on revegetation of disturbed areas in the forest-tundra ecotone in northern Fennoscandia', Landscape Ecology vol. 20, pp. 351-359.

Otręba, A 2014, 'Czeremcha amerykańska' [Black cherry], in Inwazyjne gatunki roślin w Kampinoskim Parku Narodowym i jego sąsiedztwie, eds A Otręba \& D Michalska-Hejduk, Kampinoski Park Narodowy, Izabelin, pp. 69-73.

Otręba, A\& Mędrzycki, P 2009, 'Inwazja czeremchy amerykańskiej Prunus serotina Ehrh w Kampinoskim Parku Narodowym jako efekt działalności człowieka i ekspansywnych cech gatunku' [The invasion of Prunus serotina Ehrh in Kampinos National Park resulting from anthropogenic activity and expansive species characteristics], in Trwałość i efektywność ochrony przyrody w polskich parkach narodowych, eds A Andrzejewska \& A Lubański, Kampinoski Park Narodowy, Izabelin, pp. 259-270.

Parlane, S Sunners, RW Cowie, NR \& van Gardingen, PR 2006 'Management proposals for bilberry in Scots pine woodland', Forest Ecology \& Management vol. 222, pp. 272-278.

Pawłowski, B \& Zarzycki, K 1972, 'Dynamika zbiorowisk roślinnych' [Dynamics of plant communities], in Szata roślinna Polski, eds W Szafer \& K Zarzycki, Państwowe Wydawnictwo Naukowe, Warszawa, vol. 1, pp. 481-501.

Peterken, GF 1977, 'Habitat conservation priorities in British and European woodlands', Biological Conservation vol. 11, pp. 223-236.

Pyšek, P Prach, K Rejmánek, M \& Wade, M (eds) 1995, Plant invasions: general aspects and special problems, SPB Academic Publishing, Amsterdam.

Rackham, O 1980, Ancient woodland its history, vegetation and uses in England, Arnold, London.

Reinecke, J Klemm, G \& Heinken, T 2014, 'Vegetation change and homogenization of species composition in temperate nutrient deficient Scots pine forests after $45 \mathrm{yr}$ ', Journal of Vegetation Science vol. 25(1), pp. 113-121.

Reinikainen, A Mäkipää, R Vanha-Majamaa, I \& Hotanen, J-P 2000, Kasvit Muuttuvassa Mestäluonossa [Changes in the frequency and abundances of forest and mire plants in Finland since 1950], Kustannusosakeyhtiö Tammi, Helsinki, FI.

Solon, J 1994, Roślinność Kampinoskiego Parku Narodowego i jego otuliny [The vegetation of Kampinos National Park and its buffer zone], NFOŚ, Warszawa.

Solon, J 2003, 'Dynamika roślinności Kampinoskiego Parku Narodowego i jego otuliny' [Dynamics of vegetation in Kampinos National Park and its buffer zone], in Kampinoski Park Narodowy, ed R Andrzejewski, Kampinoski Park Narodowy, Izabelin vol. 1, pp. 413-429.

Stefańska-Krzaczek, E 2010, 'Plant communities of Scots pine stands in the south-eastern part of the Bory Dolnośląskie forest (SW Poland)', Acta Botanica Silesiaca Monographiae vol.6, pp. 3-98.

Tokarska-Guzik, B 2005, 'The Establishment and Spread of Alien Plant Species (Kenophytes) in the Flora of Poland', Prace Naukowe Uniwersytetu Śląskiego vol. 2372, Katowice.

Tomanek, J 1997, Botanika leśna [Forest botany], PWRiL, Warszawa.

Tüxen, R 1956, 'Die heutige potentielle naturliche Vegetation als Gegenstand der Vegetationskartierung', Angew Pflanzensoz 13, pp. 5-42.

Wulf, M 2003, 'Preference of plant species for woodlands with different habitat continuities', Flora vol. 198, pp. 444-460.

Verheyen, K Bossuyt, B Hermy, M \& Tack, G 1999, 'The land use history (1278-1990) of a mixed hardwood forest in western Belgium and its relationship with chemical soil characteristics', Journal of Biogeography vol. 26, pp. 11151128.

Zielony, R 2004a, 'Zarys dziejów gospodarki leśnej w Puszczy Kampinoskiej' [An outline history of forest management in the Kampinos Forest], in Kampinoski Park Narodowy, ed R Andrzejewski, Kampinoski Park Narodowy, Izabelin vol. 2, pp. 87-109.

Zielony, R 2004b, 'Lasy Kampinoskiego Parku Narodowego na przełomie XX i XXI wieku' [The forests of Kampinos National Park in the late 20th and early 21st centuries], in Kampinoski Park Narodowy, ed R Andrzejewski, Kampinoski Park Narodowy, Izabelin vol. 2, pp. 111-144. 